\title{
Groundwater suitability for irrigated agriculture in alluvial Bengal delta plain: a review
}

\author{
Md. Shajedul Islam, M. G. Mostafa \\ Institute of Environmental Science, University of Rajshahi, Rajshahi, Bangladesh
}

\begin{tabular}{l}
\hline Article Info \\
\hline Article history: \\
Received Oct 12, 2020 \\
Revised Jan 23, 2021 \\
Accepted Feb 3, 2021 \\
\hline
\end{tabular}

\section{Keywords:}

Bengal basin

BGM delta

Irrigation groundwater quality

IWQ index

Salinity hazard

Soil permeability

\begin{abstract}
Groundwater is a vital source of irrigation and domestic purposes in Bangladesh, and hence, it must satisfy the water quality guidelines. The study has selected 11 districts of Bangladesh and collected secondary data regarding the irrigation water quality of groundwater. Several irrigation water indices, such as soluble sodium percentage (SSP), sodium adsorption ratio (SAR), magnesium adsorption ratio (MAR), residual sodium carbonate (RSC), Kelly's ratio (KR), permeability index (PI), and irrigation water quality (IWQ) index are applied to evaluate irrigation water quality. According to IWQindex, the results showed $25.5 \%$ of water samples fell in a highly suitable water type, whereas $33.5 \%$ exhibited a low suitability type, and the remaining $41 \%$ showed medium suitability for irrigation purposes. The values of SAR, SSP, RSBC, and MAR indices showed that about $31-64 \%$ of water samples were very good, whereas $5-20 \%$ were very poor for the same purpose. The results of TDS, EC, and total hardness showed good results as $88-93 \%$ of water samples fell in fair to excellent quality. The salinity hazard was found in the groundwater of coastal areas and was completely unfit for irrigation. The study findings would help for improving the management of the groundwater resources for agricultural purposes in Bangladesh.
\end{abstract}

This is an open access article under the CC BY-SA license.

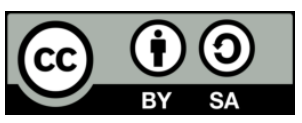

Corresponding Author:

M. G. Mostafa

Institute of Environmental Science

University of Rajshahi

Rajshahi 6205, Bangladesh

Email: mgmostafa@ru.ac.bd

\section{INTRODUCTION}

Bengal delta basin (BDB) is covered by alluvial sedimentary soil with enough thick deposited by the Ganges, Brahmaputra, and Meghna (GBM) rivers. It is one of the biggest deltas and widespread fertile cultivable land in the world [1]. Two Himalayan rivers the Ganges and the Brahmaputra are both fall to the Bay of Bengal as a collective river transport the largest sediment load. These two rivers join central Bangladesh with the Meghna, a non-Himalayan river that creates the largest delta in the world named the Bengal delta. This delta is one of the most widespread alluvial or sediment basins and establishes the delta plain and the lowers floodplain deposits of Bangladeshis at the mouth of the Ganga-Brahmaputra-Meghna (GBM) river systems. The Ganga-Brahmaputra river systems together carry the largest sediment load of 
the world, which transport about $80 \%$ of the sediment load during the rainy season [2]. More than 200 rivers and streams run through Bangladesh, with a mean annual discharge of water of about $38,000 \mathrm{~m}^{3} / \mathrm{s}[3]$, carrying over $2.4 \times 109$ MT of sediments every year before discharging lastly into the Bay of Bengal [4]. The huge alluvial sediments washed away and deposited in basin areas and finally, made it a bigger arable region in the world. Bangladesh is a densely populated (2890 per mile ${ }^{2}$, which ranks $10^{\text {th }}$ in the world) and agrarian country Figure 1. Almost $90 \%$ of its lands are cultivable and $55 \%$ of the inhabitant are engaged in the agricultural sector [5]. This sector plays a vital role in the country's economy, which accounts for about $21 \%$ of involvement in countrywide GDP [5]. Nevertheless, still now, agriculture is being conducted in nonsustainable, unplanned, and unsystematic ways. Besides, due to the geogenic and anthropogenic causes, the quality of irrigation water deteriorates progressively, which affects the soil environment and crop production.

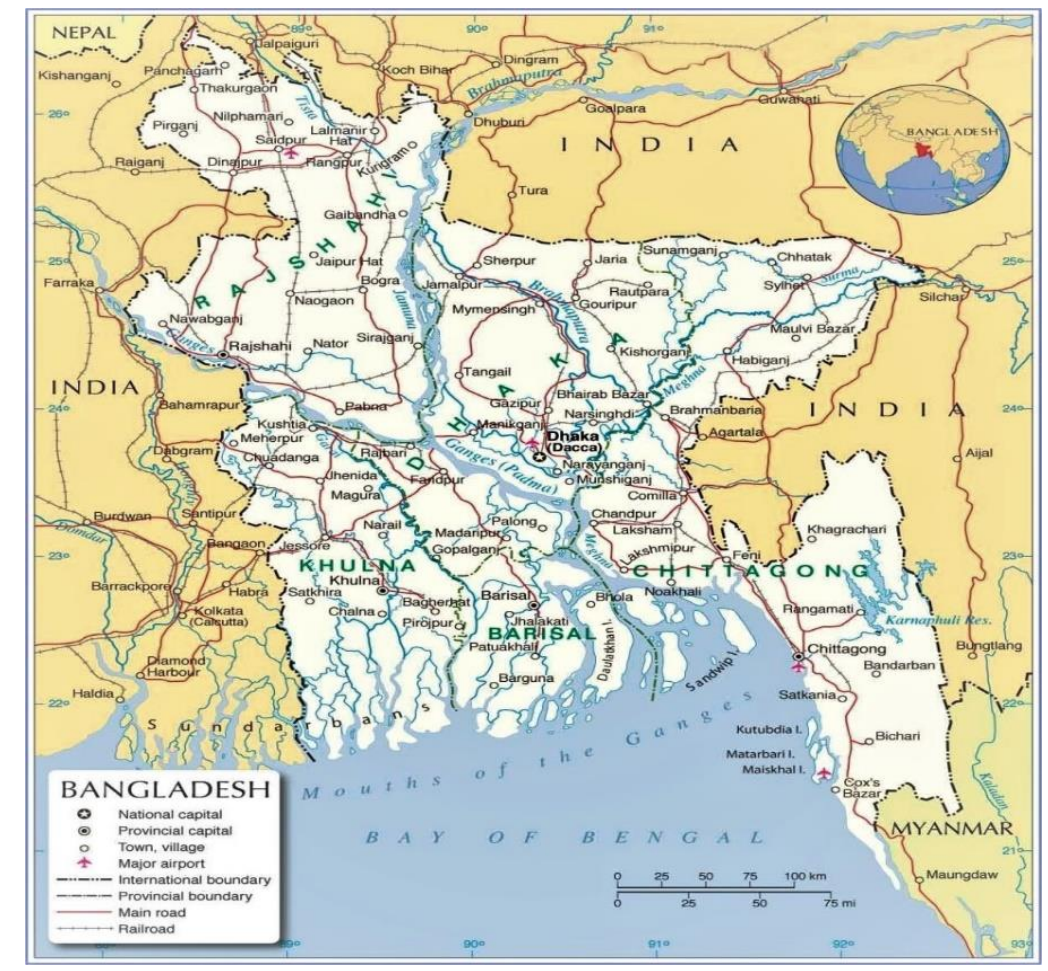

Figure 1. Administrative map of Bangladesh

In Bangladesh (BDB), before the 1970s, agriculture was completely dependent on surface water and seasonal monsoon rainfall [6]. Later that time to harvest high-yielding rice varieties and to attain success the global campaign of clean and fresh drinking water decade (1980-1990), millions of drinking and irrigation shallow and deep-water wells have installed in Bangladesh [7]-[9]. Now a day, rather than surface water, groundwater is the main source of irrigation in the country [10]. By 2006, almost $78 \%$ of the irrigated paddyfields were supplied by groundwater of which nearly $80 \%$ of the irrigation water derived from shallow $(25-40 \mathrm{~m})$ engine tube-wells, and the rest was irrigated by deep $(100-150 \mathrm{~m})$ tube-wells [11], [12]. Such irrigation water desires to be of suitable quality. The chemical characteristics of irrigation water can affect plant growth and crop quality directly through nutrients deficiency or toxicity, or indirectly by the degradation of soil quality [13]. The bad quality irrigation water reduces the soil productivity as well as changes in soil physical and chemical properties. It also creates crop toxicity and ultimately reduces the yield of the crop [14], [15]. Now a day, arsenic contamination is a threat to irrigation water. Besides, presently groundwater is considered to be the only resource for irrigation water supply in the country. Therefore, its rational use should ensure in terms of both quality and quantity [16]. So, information regarding irrigation water quality is imperative to understand the necessity of agro-management for long-term productivity [17].

Agricultural development, land use and crop diversity, rapid urbanization and industrialization, and anthropogenic pollution have direct or indirect impacts on groundwater quality. Irrigated agriculture mostly depends on groundwater resources worldwide [18]. The situation in Bangladesh concerning water distribution for irrigation is similar to other lower-middle-income countries in the world [19]. Unfortunately, in the recent past decade, irrigation groundwater use by open canals has caused a rapid decline in water reserves and levels in many regions of Bangladesh [20]. Groundwater resource is vulnerable not only the

Groundwater suitability for irrigated agriculture in alluvial Bengal delta ... (Md. Shajedul Islam) 
overexploitation during irrigation, but also geogenic and anthropogenic contamination. Quality of water is vital for each type of cultivation since poor quality irrigation water may lead to a huge economic loss and a reduction in crop production. Besides, long-term agricultural productivity can sustain if irrigation water quality is properly monitored [21]. So, the irrigation water quality might be influenced by the concentrations of various physiochemical parameters dissolved in water resulting from water-rock interactions and anthropogenic activities.

Many investigators revealed the groundwater quality of different districts of Bangladesh for irrigation purpose, and they were: Mridha [22] explored groundwater at Natore district, Faridpur district's groundwater investigated by Islam [23], Quddus and Zaman [24] studied the irrigation water quality of some selected villages of Meherpur district, Talukder [25] conducted an extensive study on groundwater of Kishoreganj district, Sarkar and Hassan [16] assessed the groundwater of Pabna district for irrigation, Shahidullah [26] and Sultana [27] investigated the groundwater quality in Mymensingh and Khulna districts, respectively. Raihan and Alam [28] analyzed groundwater quality throughout the Sunamganj district, Islam and Shamsad [29] assessed groundwater quality of Bogra district, and Rahman [30] studied groundwater quality of Satkhira district for irrigation purpose. A study on groundwater illustrated that the groundwater in coastal areas was not suitable for irrigation purposes in the pre-monsoon season. However, it was found suitable for the monsoon and post-monsoon seasons [31].

Quite a lot of irrigation water quality indexes are usually followed to assess water quality in literature. Indeed, irrigation water quality (IWQ) indexes are expected to deliver a simple tool for water managers and policymakers on the quality and potential uses of a given aquifer system. At first, Horton [32] proposed an integrated WQIs for assessing water quality. Since then, many water quality indices reported by several investigators worldwide [19], [33]-[37], for example, Simsek and Gunduz [38] have developed a GIS-based irrigation water quality (IWQ) index by combining well-known hydrochemical parameters (TDS, EC, RSC, SAR, and others) to assess the irrigation water quality of the Simav Plain in Turkey. Ashraf [39] developed a GIS-based irrigation water index for calculating SAR, RSC, or SSP with other parameters. Romanelli et al. (2012) assessed groundwater quality for suitability of irrigation purposes using the IWQ index $_{\text {. }}$ [40]. The index integrated the hydro-chemical, hydrogeological, and topographic parameters (EC, SAR, RSC, slops, hydraulic gradient, and aquifer thickness). In this paper, we try to assess the countrywide irrigation groundwater quality through the calculation of various parameters such as soluble sodium percentage (SSP), residual sodium bicarbonate (RSC), Kelley's ratio (KR), permeability index (PI), and magnesium adsorption ratio (MAR). Thus, the study aimed to assess the suitability of irrigation water in Bangladesh using several indices. Besides, countrywide soil permeability, hydraulic conductivity of soil, soil class. Also assessed by this study. However, the results of this study provide a guideline for an agricultural manager, hydrologist, policymakers, and water planner of a certain aquifer system to take a suitable initiative for groundwater quality management in the selected region.

\section{STUDY AREA-GEOMORPHOLOGY, HYDROLOGY, AND WATER TYPE}

\subsection{Geomorphology}

The chemistry of groundwater typically depends on the local geological setting in aquifers. In this section, we draw a picture briefly of the aquifer geomorphology of Bangladesh. There are four major physiographic regions, i.e., (i) Pleistocene courtyard in the Barind and Madhupur zones (ii) tertiary alluvial in the eastern and northern hills (iii) the delta covers the rest of the country, and (iv) Holocene (recent) floodplains of the Ganges, Brahmaputra, and Meghna (GBM) river exist at the surface in the country [41], [42]. The hydrogeological cross-sectional view of Bangladesh from north to the south showing the aquifer system and groundwater flow outline shown in Figure 2. Historically, around 6,000 years ago the sea level was much lower, and the main rivers divided deep channels surrounding the Barind and Madhupur tract zone [43]. With some Pleistocene terraces, deltaic flood plains comprise the main portion of the basin and its sediments consist mostly of unconsolidated deltaic deposits and alluvial except for the mixed geology zone of pre-quaternary deposits that cover the north-eastern and southeastern mountainous areas of Bangladesh. Collected with the tertiary alluvial arrangements the maximum depth of the layout is mostly $20 \mathrm{~km} \mathrm{[44].} \mathrm{The}$ country has promising hydrogeologic conditions and tropical monsoon weather indicates possible storing of groundwater in the aquifers. The uncombined nearby-surface Pleistocene to recent estuarine and fluvial sediments underlying most of the country usually form productive aquifers. Deep semi-contracted to the uncontracted fluvial-deltaic deposit of Miocene age to the recent forms of many aquifers. But excluding the Dupi Tila sandstone construction of the plio-Pleistocene stage, others are too deep to consider for groundwater withdrawal except in the mountainous region (18\% of total areas) [43]. Most of the groundwater extraction for irrigation or domestic purposes in the Barind and Madhupur upland areas are from the Dupi Tila aquifers. The floodplains of the active/inactive delta plain and the major rivers of the GBM delta 
complex occupies about $82 \%$ of the country area [7]. The geological studies indicated that the bulk of the best aquifers occurs from 30 to $130 \mathrm{~m}$ depth [41]. These alluvial deposits are cyclic sediment of typically medium to fine sand, clay, silt, and siltstone. The separate layers cannot trace for long distances, vertically or horizontally [7], [45].

Rain and floodwater are the principal sources of groundwater recharge in Bangladesh. Numbers of studies forecast that vast groundwater-fed irrigation would prolong net recharge in areas where soil properties and surface lithology are good permeable that favor recharge [6], [46], [47]. The study projected area wise annual usable and potential recharge between 183 to $1287 \mathrm{~mm}$ and 135 to $1910 \mathrm{~mm}$, respectively. The approximations of net recharge in Bangladesh have increased from $132 \mathrm{~mm} / \mathrm{yr}$ over a period from 1975 to 1980 to about $190 \mathrm{~mm} / \mathrm{yr}$ for the period of 2002 to 2007 [47]. Recent past studies confirmed that the ratio of groundwater recharge and abstraction in the country gradually downfall.

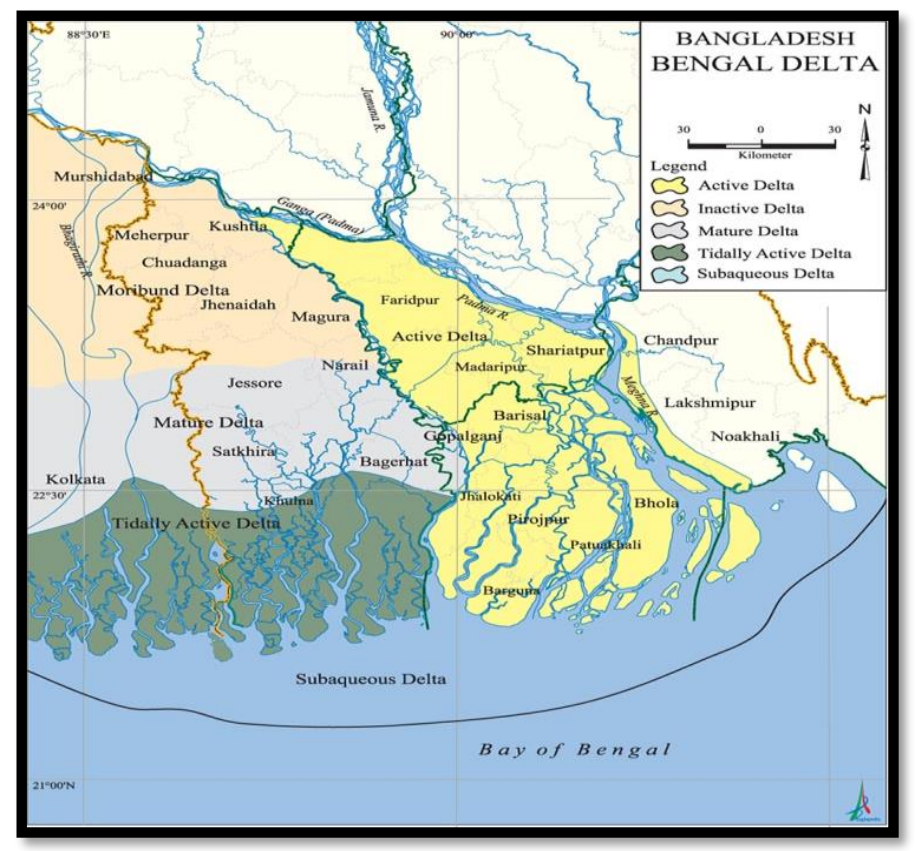

Figure 2. Map of Bengal delta plain (BDP)

\subsection{Hydrogeology}

Very productive aquifers occur underneath both the Pleistocene terraces and Holocene floodplains, the shallowest usually encountered within 15 to $45 \mathrm{~m}$ of the surface. In Bangladesh, most shallow irrigation water wells are less than $50 \mathrm{~m}$ deep. Generally, 50-75\% of the sequence can effectively develop to this depth [46]. Saline groundwater is present in parts of the coastal area and some inland zones [48]. In the coastal zones, freshwater aquifers are encountered either within the first $20 \mathrm{~m}$ or below about 100-150 m depth. An equal deeper aquifer is also exploited at some towns in the north of the coastal zone [49], following an aquitard, which is present in places but seems not to be locally extensive.

\subsection{Water quality}

In the region of BDP, before the detection of arsenic contamination, the physio-chemical quality of groundwater underneath the Holocene flood plains was thought to be commonly good, although the shallow groundwater is vulnerable to contamination by some essential and non-essential metals and microbes [50]. Calcium and iron were known as an extensive nuisance, and saltiness a constraint in the shallow layer of the coastal area. Besides, arsenic, the Department of Public Health Engineering (DPHE) identified Mn and B as common, naturally occurring ingredients, present in places above the WHO guidelines for potable water $(0.5$ $\mathrm{mg} / \mathrm{l}$ in both cases) [49]. But these elements are good for irrigation water. The groundwater type of Bangladesh is mostly $\mathrm{Ca}-\mathrm{Mg}-\mathrm{HCO}_{3}$ accomplished with high minerals (EC: 500-2000 $\mu \mathrm{S} / \mathrm{cm}$ ) and Na-Cl type water adjacent to the coastal areas. This contrasts with groundwater from the sandy aquifer of Dupi Tila underneath the Pleistocene, which is generally of the $\mathrm{Na}-\mathrm{HCO}_{3}$ type and has fewer minerals (EC: 300-600 $\mu \mathrm{S} / \mathrm{cm}$ ) [50]. Groundwater underneath the Holocene flood plains in the country is considered by high bicarbonate loads, with $\mathrm{HCO}_{3}{ }^{-}$usually present in more than a hundred $\mathrm{mg} / \mathrm{L}$. It is mostly anoxic and mostly has a strongly reducing environment, nearby to the extent of methanogenesis [51]. In this area, arsenic 
concentration is very high $(50-1000 \mu \mathrm{g} / \mathrm{L})$ combined with a high dissolved iron present at a range of $5-10 \mathrm{mg} / \mathrm{L}$. Manganese usually exceeds $0.5 \mathrm{mg} / \mathrm{l}$. Nitrate and Sulphate concentration is normally low below the Holocene floodplains, mostly less than about $5 \mathrm{mg} / \mathrm{L}$ [52], [53]. These chemical characteristics reflect the conditions of groundwater quality as well as irrigation water quality.

\section{METHODS AND MATERIALS}

Though out the review process, we used secondary data from several published articles and reports. This study searched Google Scholar, Scopus, Web of Science, PubMed, and other databases for publications across 25 years and dated 1995 to 2020 . The following terms were searched using the boolean operators 'and' and 'or': (a) Bengal delta plain, (b) geochemistry of groundwater in Bangladesh, (c) irrigation water quality, (d) IWQ index, (e) geological formation of Bengal basin, and (f) water class. Primarily, we were identified over 150 published papers and reports, but finally included 120 articles in the high impact journal. Here, we follow the PRISMA Statement for every event of inclusion and exclusion criteria. Extracted data are included in a table and assessed the irrigation water quality, soil permeability, and soil class of Bangladesh through the table. For these purposes, various well-recognized indexes and theories for irrigation water quality evolution were used.

\subsection{Irrigation water quality index (IWQ $\left.Q_{\text {index }}\right)$}

The IWQ index is prepared based on the linear correlation of four sets of irrigation water quality parameters that are connected to form a single index value to assess the irrigation water quality in Bangladesh. According to the guiding principle offered by Ayers and Westcot [33], four categories of irrigation water quality parameters, for instance, definite ion toxicity, permeability hazard, salinity threat, and associated effect are designated Table 1. Simsek and Gunduz [38] were designated detailed standard measures for irrigation water quality indexes. All parameters are given a weight factor Table $2 \&$ Table 3 from the 4 (highest) and 1 (lowest) points in the method. Among those 4 factors, salinity peril is the most vital factor, and the highest priority (weight $=4$ ), whereas the associated effects on sensitive crops are the least significant factor in the assessment of irrigation water quality. The rest of the two parameters such as permeability hazard and definite ion toxicity rated in declining order along with importance for irrigating water quality. The irrigation water quality index is measured by the using (1) and (2):

$$
I W Q_{\text {index }}=\sum_{i=1}^{4} G i
$$

where, $i=$ incremental index, and $G=$ contribution of each one of the four hazard groups that are vital to assess the quality of specific irrigation water resource; and $G$ can be calculated by:

$$
G=\frac{w}{N} \sum_{k=1}^{N}\left(r_{k}\right)
$$

here, $k=$ incremental index; $N=$ total number of parameters for the analysis; $w=$ weight value of the category; and $\mathrm{r}=$ rating value of individually parameter as given in Table 2 and Table 3.

\begin{tabular}{|c|c|c|c|c|c|}
\hline \multirow{2}{*}{ Potential problem in irrigation } & \multirow{2}{*}{ Parameters } & \multirow{2}{*}{ Units } & \multicolumn{3}{|c|}{ Grade of restriction on use } \\
\hline & & & None & Slight to moderate & Severe \\
\hline \multirow{2}{*}{$\begin{array}{l}\text { Salinity (effects water } \\
\text { availability for crop) }\end{array}$} & TDS & $\mathrm{mg} / \mathrm{L}$ & $<450$ & $450-2000$ & $>2000$ \\
\hline & EC & $\mu \mathrm{S} / \mathrm{cm}$ & $<700$ & $700-3000$ & $>3000$ \\
\hline \multirow{5}{*}{$\begin{array}{l}\text { Permeability (effects rate of water } \\
\text { infiltration into soil) }\end{array}$} & $\mathrm{SAR}=0-3$ & $\%$ & $\mathrm{EC}:>700$ & $700-200$ & $<200$ \\
\hline & $\mathrm{SAR}=3-6$ & $\%$ & EC: $>1200$ & $1200-300$ & $<300$ \\
\hline & $\mathrm{SAR}=6-12$ & $\%$ & EC: $>1900$ & $1900-500$ & $<500$ \\
\hline & $\mathrm{SAR}=12-20$ & $\%$ & EC: $>2900$ & $2900-1300$ & $<1300$ \\
\hline & $\mathrm{SAR}=20-40$ & $\%$ & $\mathrm{EC}:>5000$ & $5000-2900$ & $<2900$ \\
\hline \multirow{3}{*}{$\begin{array}{l}\text { Specific ions toxicity (effects } \\
\text { sensitive type crops) }\end{array}$} & Sodium & $\mathrm{mEq} / \mathrm{L}$ & $<3.0$ & $3.0-9.0$ & $>9.0$ \\
\hline & Boron & $\mathrm{mg} / \mathrm{L}$ & $<0.7$ & $0.7-3.0$ & $>3.0$ \\
\hline & Chloride & $\mathrm{mg} / \mathrm{L}$ & $<140$ & $140-350$ & $>350$ \\
\hline \multirow{2}{*}{$\begin{array}{l}\text { Miscellaneous effects (effects } \\
\text { vulnerable crops) }\end{array}$} & Bicarbonate & $\mathrm{mg} / \mathrm{L}$ & $<90$ & $90-500$ & $>500$ \\
\hline & $\mathrm{pH}$ & - & \multicolumn{3}{|c|}{ Normal range: $6.5-8.4$} \\
\hline
\end{tabular}

Table 1. Classification of irrigation water quality standards (according to, ayers and westcot [33]) 
Table 2. Cataloguing for IWQ index parameters (according to, ayers and westcot [33])

\begin{tabular}{|c|c|c|c|c|c|}
\hline Hazard & Weight & Parameter & Range & Rating & Suitability \\
\hline \multirow[t]{6}{*}{ Salinity hazard } & 4 & $\begin{array}{l}\text { Electrical conductivity } \\
(\mu \mathrm{S} / \mathrm{cm})\end{array}$ & $\mathrm{EC}<700$ & 3 & High \\
\hline & & & $700 \leq \mathrm{EC} \leq 3000$ & 2 & Medium \\
\hline & & & $\mathrm{EC}>3000$ & 1 & Low \\
\hline & & $\begin{array}{l}\text { Total dissolved solids } \\
(\mathrm{mg} / \mathrm{L})\end{array}$ & TDS $<450$ & 3 & High \\
\hline & & & $450 \leq \mathrm{TDS} \leq 2000$ & 2 & Medium \\
\hline & & & TDS $>2000$ & 1 & Low \\
\hline $\begin{array}{l}\text { Permeability and } \\
\text { Infiltration hazard }\end{array}$ & 3 & $\begin{array}{l}\text { See Tab. } 4 \text { and } 5 \mathrm{a} \text { for } \\
\text { details }\end{array}$ & & & \\
\hline \multirow[t]{9}{*}{ Specific ion toxicity } & 2 & $\begin{array}{l}\text { Sodium adsorption } \\
\text { ratio }(\%)\end{array}$ & SAR $<3.0$ & 3 & High \\
\hline & & & $3.0 \leq \mathrm{SAR} \leq 9.0$ & 2 & Medium \\
\hline & & & SAR $>9.0$ & 1 & Low \\
\hline & & Boron (mg/L) & $\mathrm{B}<0.7$ & 3 & High \\
\hline & & & $0.7 \leq \mathrm{B} \leq 3.0$ & 2 & Medium \\
\hline & & & $\mathrm{B}>3.0$ & 1 & Low \\
\hline & & Chloride (mg/L) & $\mathrm{Cl}<140$ & 3 & High \\
\hline & & & $140 \leq \mathrm{Cl} \leq 350$ & 2 & Medium \\
\hline & & & $\mathrm{Cl}>350$ & 1 & Low \\
\hline \multirow{6}{*}{$\begin{array}{l}\text { Assorted effects to } \\
\text { sensitive crop }\end{array}$} & 1 & Bicarbonate $(\mathrm{mg} / \mathrm{L})$ & $\mathrm{HCO} 3<90$ & 3 & High \\
\hline & & & $90 \leq \mathrm{HCO} 3 \leq 500$ & 2 & Medium \\
\hline & & & $\mathrm{HCO} 3>500$ & 1 & Low \\
\hline & & $\mathrm{pH}$ & $7.0 \leq \mathrm{pH} \leq 8.0$ & 3 & High \\
\hline & & & $\begin{array}{l}6.5 \leq \mathrm{pH}<7.0 \text { and } 8.0 \\
<\mathrm{pH} \leq 8.5\end{array}$ & 2 & Medium \\
\hline & & & $\mathrm{pH}<6.5$ or $\mathrm{pH}>8.5$ & 1 & Low \\
\hline
\end{tabular}

Table 3. Classification for infiltration and permeability hazard

\begin{tabular}{|c|c|c|c|c|c|c|c|}
\hline & \multicolumn{5}{|c|}{ SAR (\%) } & \multirow{2}{*}{ Rating } & \multirow{2}{*}{ Suitability } \\
\hline & $<3$ & $3-6$ & $6-12$ & $12-20$ & $>20$ & & \\
\hline \multirow[t]{3}{*}{ EC } & $>700$ & $>1200$ & $>1900$ & $>2900$ & $>5000$ & 3 & High \\
\hline & $700-200$ & $1200-300$ & $1900-500$ & $2900-1300$ & $5000-2900$ & 2 & Medium \\
\hline & $<200$ & $<300$ & $<500$ & $<1300$ & $<2900$ & 1 & Low \\
\hline
\end{tabular}

\subsection{Methods for hydrogeochemical and water quality evaluation}

In the agricultural sector, utilization of bad water quality can make four types of problems such as toxicity hazard, water impermeability, salinity hazard, and miscellaneous [33]. Water quality assessment of irrigation, there are four most common criteria like EC or TDS; residual sodium carbonate (RSC); sodium adsorption ratio (SAR); concentration of some ions like $\mathrm{Na}^{+}, \mathrm{HCO}_{3}{ }^{-} / \mathrm{CO}_{3}{ }^{2-}$, and $\mathrm{Cl}^{-}$[54], [55]. For the present irrigation water quality assessment besides the separate chemical parameters, the following parameters have been considered. To assess countrywide water quality for irrigation the following parameters were calculated and the results are included in Table 5 and Table 6:

a. The total hardness (TH) in ppm [55]-[57] was determined by as (3).

$$
T H=2.497 \mathrm{Ca}^{2+}+4.115 \mathrm{Mg}^{2+}
$$

b. To assess the water quality for irrigation, the alkali or sodium hazard stated by the sodium adsorption ratio (SAR) is extensively used [19], [58]. If water samples with high $\mathrm{Na}^{+}$and low $\mathrm{Ca}^{2+}$ concentration, the ion exchange complex may become saturated with $\mathrm{Na}^{+}$which abolishes the soil architecture [56]. The SAR value of irrigation water calculates the relative proportion of $\mathrm{Na}^{+}$to $\mathrm{Ca}^{2+}$ and $\mathrm{Mg}^{2+}$ [59], and According to Richards [60], sodium adsorption ratio (SAR) is expressed as (4):

$$
S A R=\frac{N a^{+}}{\sqrt{\left(C a^{2+}+M g^{2+}\right) / 2}}
$$

where, $\mathrm{Na}^{+}, \mathrm{Ca}^{2+}$ and $\mathrm{Mg}^{2+}$ are expressed as the concentrations $(\mathrm{mEq} / \mathrm{L})$ of $\mathrm{Na}, \mathrm{Ca}$, and $\mathrm{Mg}$ ions in water, respectively [33]. 
c. Soluble sodium percentage (SSP) or $\% \mathrm{Na}$ was used to evaluate the sodium hazard in irrigation water. Todd [56] established SSP or \% Na as (5):

$$
\text { SSP or } \% N a=\frac{\left(N^{+}+K^{+}\right) \times 100}{\left(C a^{2+}+M g^{2+}+N a^{+}+K^{+}\right)}
$$

d. The residual sodium carbonate (RSC) is calculated taking the alkaline earths ( $\mathrm{Ca}$ and $\mathrm{Mg}$ ) and weak acids $\left(\mathrm{H}_{2} \mathrm{CO}_{3}\right)$ as (6) [55], [61]:

$$
S C=\left(\mathrm{CO}_{3}^{2-}+\mathrm{HCO}_{3}^{-}\right)-\left(\mathrm{Ca}^{2+}+\mathrm{Mg}^{2+}\right)
$$

e. Gupta [62] expressed residual sodium bicarbonate (RSBC) as (7):

$$
\mathrm{SBC}=\mathrm{HCO}_{3}{ }^{-}-\mathrm{Ca}^{2+}
$$

f. Doneen [63] defined permeability index (PI) as (8):

$$
P I=\frac{\mathrm{Na}^{+}{\sqrt{\mathrm{HO}_{3}}}^{-}}{\left(\mathrm{Na}^{+}+\mathrm{Ca}^{2+}+\mathrm{Mg}^{2+}\right)} \times 100
$$

g. Magnesium adsorption ratio (MAR) also recognized as magnesium hazard was calculated [55] as (9):

$$
M A R=\frac{\left(M g^{2+} \times 100\right)}{\left(C a^{2+}+M g^{2+}\right)}
$$

h. Lastly, Kelley's ratio (KR) [64] described as (10).

$$
K R=\frac{N a^{+}}{\left(C a^{2+}+M g^{2+}\right)}
$$

All ionic parameter concentrations are in $\mathrm{mEq} / \mathrm{L}$. All these parameters and individual physicochemical parameters have compared with national and international standards to assess the groundwater suitability for irrigation. The values of all the above parameters of countrywide groundwater samples are reported in Table 5 and Table 6.

\section{RESULTS AND DISCUSSION}

In Bangladesh, groundwater is the main source of irrigation, which is around 30 to $40 \%$ of net tillable land [10], [65]. The groundwater contribution to the whole irrigated zone increased expressively from $41 \%$ in 1983 to $86 \%$ in 2002 [66]-[68]. Several studies illustrated that the overexploitation of groundwater and other anthropogenic activities are the cause of groundwater level and quality degradation. The water class used for irrigation is vital for the yield and number of crops, protection of the hydrological environment, and preservation of soil productivity. The physical and mechanical properties of the soil, soil permeability, and ex. soil structure (aggregational stability) are very sensorial to the type of transferable chemical constituent present in irrigation water.

The $\mathrm{pH}, \mathrm{Na}$ hazard, salinity hazard, some trace elements, bicarbonate, and carbonate in connection with the $\mathrm{Mg}$ and $\mathrm{Ca}$ content, toxic anion, free $\mathrm{Cl}$, and nutrients are the most crucial factors to regulate the suitability of water use in irrigation [69]. Besides, according to Michael [54], Raghunath [55], Matthess [70], and Guy [71] the agriculture water quality is decided by the 4 most admissible criteria such as TDS or EC, the level of certain specific elements like $\mathrm{Na}, \mathrm{K}, \mathrm{Mg}, \mathrm{Ca}, \mathrm{Cl}$ and/ or $\mathrm{Br}$ contents; the relative quantity of $\mathrm{Na}$ to other cation, denoted by sodium adsorption ratio (SAR); and residual sodium carbonate and bicarbonate (RSC \& RSBC). Apart from these, other measures like the presence of soil hardpan, the depth of the water layer, $\mathrm{CaCO} 3$ level in the soil, $\mathrm{K}$ and NO3 ions have influenced the appropriateness of irrigation water indirectly [54]. Besides, Matthess [70] and Ayers and Westcot [33] described that poor-quality irrigation water creates 4 types of problems; specific ion toxicity (affects sensitive crops), salinity (effects crop water availability), water permeability (effects penetration rate of water into the soil), and miscellaneous [71], [72]. The values of including previously discussed parameters, other parameters such as soluble sodium percentage (SSP), residual sodium bicarbonate (RSC), Kelley's ratio (KR), permeability index (PI), and magnesium adsorption ratio (MAR) of countrywide irrigation groundwater samples have included in Table 5. Also, the 
limits of some important indices for rating water quality and its suitability for irrigation purposes are presented in Table 4.

Table 4. Limits of important parameter indices for rating groundwater quality for irrigation use

\begin{tabular}{|c|c|c|c|c|c|c|c|c|c|}
\hline \multirow{2}{*}{$\begin{array}{l}\text { Category } \\
\text { (Water } \\
\text { class) }\end{array}$} & \multicolumn{8}{|c|}{ Irrigation water quality indices } & \multirow{2}{*}{$\begin{array}{l}\text { Degree on } \\
\text { restriction } \\
\text { on use }\end{array}$} \\
\hline & $\begin{array}{c}E C, \\
(\mu S / c m)\end{array}$ & $\begin{array}{l}\text { SAR } \\
(\%)\end{array}$ & $\begin{array}{c}S S P \\
(m e / L)\end{array}$ & $\begin{array}{c}R S C \\
(m e / L)\end{array}$ & $\begin{array}{l}P I \\
(\%)\end{array}$ & $\operatorname{MAR}(\%)$ & $\begin{array}{c}T D S \\
(\mathrm{mg} / \mathrm{L})\end{array}$ & $\begin{array}{c}\text { Salinity } \\
(\mathrm{mg} / \mathrm{L})\end{array}$ & \\
\hline I & $<700$ & $<10$ & $<20$ & 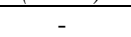 & $>75$ & - & 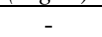 & 0 & Excellent \\
\hline II & $700-3000$ & $10-18$ & $20-40$ & $<1.25$ & $\begin{array}{l}25- \\
75\end{array}$ & $<50$ & $>2000$ & $<450$ & Good \\
\hline III & $>3000$ & $18-26$ & $40-80$ & $1.25-2.5$ & $<25$ & - & $\begin{array}{l}450- \\
2000\end{array}$ & $450-2000$ & Fair \\
\hline IV & - & $>26$ & $>80$ & $>2.5$ & - & - & $<450$ & $>2000$ & $\begin{array}{r}\text { Poor or } \\
\text { Rejection }\end{array}$ \\
\hline Ref. & $\begin{array}{c}\text { UCCC } \\
{[73]}\end{array}$ & $\begin{array}{c}\text { Fipps } \\
{[71]}\end{array}$ & $\begin{array}{c}\text { Wilcox } \\
\text { [74] }\end{array}$ & $\begin{array}{l}\text { Gupta and } \\
\text { Gupta [62] }\end{array}$ & $\begin{array}{c}\mathrm{Hem} \\
{[57]}\end{array}$ & $\begin{array}{l}\text { Gupta and } \\
\text { Gupta [62] }\end{array}$ & $\begin{array}{c}\text { Bauder } \\
{[17]}\end{array}$ & $\begin{array}{c}\text { UCCC } \\
{[73]}\end{array}$ & \\
\hline
\end{tabular}

The TH, TDS, and EC pooled value of groundwater of 11 different Districts of Bangladesh are presented in Table 6. Several reports showed that the salinity intrusion in the coastal groundwater of Bangladesh makes it unfit for irrigation purposes [16], [30], [31], [72], [75]-[77]. Again, most shallow aquifer's water, including the coastal region, of 60 districts out of 64 contaminated with arsenic [7], [78] and that used for irrigation. It has been estimated that yearly arsenic input with irrigation water is around 4.4 $\mathrm{kg} / \mathrm{ha}$ in the paddy field [79] and in rice grains, arsenic is found above $0.017 \mathrm{mg} / \mathrm{gm}$ [80]. EC and TDS are significant in considering the irrigation water quality as various toxic solid materials may embed in the water, which causes damaging the plants [70]. Regarding the degree of restriction use, TDS concentration $<450$, 450-2000, and >2000 mg/L represent the agriculture water as 'none', 'slight to moderate', and 'severe' respectively which are presented in Table 4 [73]. According to the water quality indices, the south zone is classified as 'slight to moderate' and 'severe' and both north and center areas as 'none' and 'slight to moderate.

Salinity is the dissolved salt content of a water body. It is used to designate the levels of dissimilar salts such as $\mathrm{NaCl}, \mathrm{MgSO}_{4}, \mathrm{CaSO}_{4}$, and bicarbonates. The concentration of chlorine is straight proportional to salinity, which creates from the dissociation of various chlorinated. Besides, Na and TDS are other very significant parameters that can use to detect the influence of groundwater salinity and major component loads. Dider-Ul reported that in the case of groundwater of Khulna district, $\mathrm{Na}^{+}$and $\mathrm{Cl}^{-}$are strongly positively correlated with TDS ( $r=0.87$ and 0.89 respectively) [81]. They also stated that all other parameters i.e., $\mathrm{Na}^{+} \mathrm{Ca}^{++}, \mathrm{Mg}^{++}$, and $\mathrm{K}^{+}$also well correlated with $\mathrm{Cl}^{-}(\mathrm{r}=0.90,0.88,0.87$, and 0.0 .76 respectively) so, they originated from the same sources. A countrywide study showed that According to WHO classification of groundwater based on TDS, $12 \%$ of the sample fall in excellent, $23 \%$ are good, $46 \%$ are fair, $07 \%$ poor, and $12 \%$ falls in the unacceptable category Figure 3 [82].

The values of all irrigation water quality parameters are shown in Figure 4 and Table 5 and Table 6. Box plot indicates that the EC value is twice than TH value in most of the sampling sites Figure 4. In the coastal areas, the EC, as well as TDS values, are very high rather than the other part of the country. The higher value of EC and $\mathrm{TH}$ in the groundwater samples pose a threat to crop production in the study area. RSBC and RSC values of the countrywide groundwater are almost the same, indicating the higher value of $\mathrm{Ca}$ and $\mathrm{HCO}_{3}{ }^{-}$. The SAR, SSP, PI, MAR, and KI values are shown in the box plot. The box plots Figure 4 show that the assessment of mean, median, minimum, and maximum values of SAR, SSP, and Na\% indicate similar values in the studied samples.

EC and total hardness are the important parameters that are related to groundwater salinity and freshness. According to WHO [82] salinity hazard based on EC value has been classified into four groups; low salinity hazard, medium salinity hazard, high salinity hazard, and very high salinity hazard. Wilcox drew the classification of EC as excellent, good, fair, and poor categories. The study showed that about 12, 53, 25, and $10 \%$ of water fell into excellent, good, fair, and poor categories, respectively Figure 3 [74]. The spatial distribution of groundwater showed the high EC values range from 2000 to $5000 \mu \mathrm{S} / \mathrm{cm}$ in the coastal region of Bangladesh [ref. 23: Khulna district; 84: Sathkhira district; 72: Patuakhali district]. In contrast, hardness is an important parameter for determining the suitability of groundwater for domestic, industrial, and agricultural uses [92]. It is defined as the sum of the concentration of their ion expressed in $\mathrm{mg} / \mathrm{L} \mathrm{of} \mathrm{CaCO}_{3}$. The classification of the groundwater based on hardness is presented in Figure 3 [93]. Accordingly, 62\% of samples are soft and $8 \%$ fall in the very hard category.

The value of irrigation water quality parameters such as SAR, SSP, RSC, RSBC, MAR, and KR of 11 different Districts in Bangladesh are shown in Table 5. Water permeability of soil is an important factor in 
the fertility rate of cultivable land. Permeability problem occurred when the usual percolation rate of soil significantly reduced and hampers moisture supply to crops, which is accountable for the two most water quality factors as the salinity of water and its $\mathrm{Na}$ content relative to $\mathrm{Ca}$ and $\mathrm{Mg}$ [16]. High salinity increases permeability rate in water and low salinity or water with high a $\mathrm{Na}$ to $\mathrm{Ca}$ ratio $(\mathrm{Na}$ : $\mathrm{Ca}$ ) decreases infiltration [33]. Balance of some cations and anions or comparative proportions of other different cations well-defined by SAR, SSP, RSC, RSBC, MAR, and KR. are also indicators of infiltration problems. A large proportion of $\mathrm{Na}$ in soil with chloride and carbonate or sulfate named saline or alkali soils, respectively [30. 56]. Percent of $\mathrm{Na}$ (SSP) in water reacts with soil to decrease soil permeability and its frequent use makes the soil impermeable, whereas high $\mathrm{Na}$ leads to grow of alkali soil [55]. High $\mathrm{Na}$ saturation also causes $\mathrm{Ca}$ deficiency. In contrast, the presence of $\mathrm{Ca}$ and/or $\mathrm{Mg}$ salt in irrigation water checks the bad effects of $\mathrm{Na}$ by increasing the permeability of the soil [94]. Figure 5 shows that concerning SAR, SSP, RSBC, and MRI 31$64 \%$ of water samples are very good in position, whereas $5-20 \%$ are very poor or rejected for the uses of irrigation purposes.
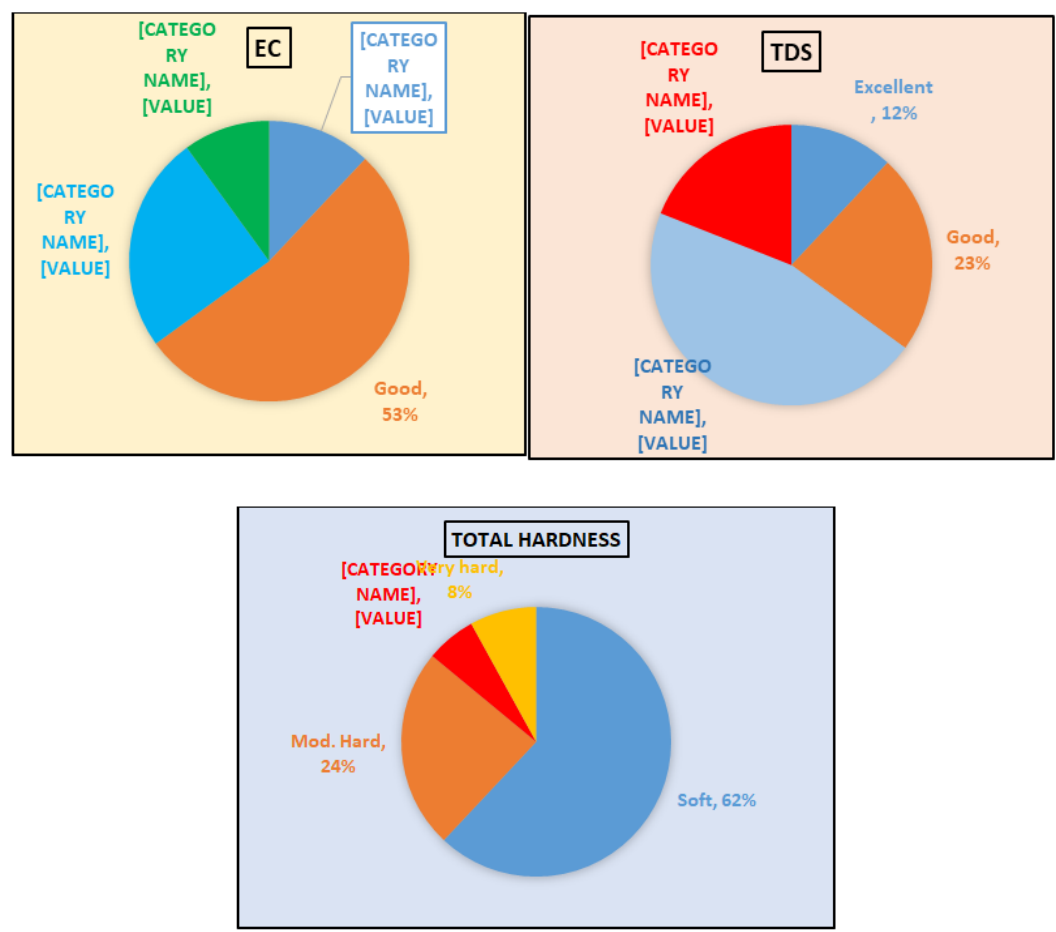

Figure 3. Countrywide (selected 11 Districts) EC, TDS, and total hardness status of groundwater

Besides, saltwater dissolves and leaches most of the soluble minerals, including $\mathrm{Ca}$ and $\mathrm{Mg}$ from the topsoil [33]. Sodium content, compare to $\mathrm{Ca}$ and $\mathrm{Mg}$ load, usually known as SAR impacts the penetration rate of water and so, low SAR is at all times desirable. In the maximum samples, SAR values ranged below 1 and classified as excellent according to the conditions set by UCCC except for the coastal areas [73] and Todd [56], which showed in Table 5. Hence, rendering to SAR, the groundwater tested was suitable for crop production. Besides, the PI value of water with $75 \%$ or more $(>75 \%)$ and KR value with less than $1(<1)$ are suitable for irrigation. Table 5 shows that the PI and KR values are good in the position except in the coastal areas. Concerning, $\mathrm{Mg}$ : $\mathrm{Ca}$ and $\mathrm{Na}$ : $\mathrm{Ca}$ values, maximum water samples have good permeability characteristics and the information on Hazard Classes are almost acceptable for irrigation Table 6. The samples of the coastal region (Khulna, Satkhira, and Patuakhali) are determined as high salinity (C3) and high/medium sodium hazard ( $\mathrm{S} 2$ or $\mathrm{S} 2$ ) i.e., the hazard classes are $\mathrm{C} 3 \mathrm{~S} 2, \mathrm{C} 2 \mathrm{~S} 2$, or $\mathrm{C} 2 \mathrm{~S} 3$ Table 6. The suitability analysis and the total value of the index of irrigation water quality are presented in Table 7 . The values given in the Table are obtained by assigning different rating factors (i.e., 1, 2, and 3) to each parameter without changing its weighting coefficient Table 2, thus yielding three different index values (i.e., 45 , 30, and 15). The medians of these values are used to set the upper and lower limits used in each class quantified in Table 7. 
Table 5. Irrigational groundwater quality of Bangladesh (11 selected District) on different quality indices

\begin{tabular}{|c|c|c|c|c|c|c|c|c|}
\hline \multirow[t]{2}{*}{ Sampling Area } & \multicolumn{7}{|c|}{ Irrigational water quality indices (mean value) and degree of water quality* } & \multirow[t]{2}{*}{ Source } \\
\hline & $\begin{array}{c}\text { SAR } \\
(\%)\end{array}$ & $\begin{array}{c}\text { SSP } \\
(\mathrm{me} / \mathrm{L})\end{array}$ & $\begin{array}{l}\text { RSBC } \\
(\mathrm{me} / \mathrm{L})\end{array}$ & $\begin{array}{c}\mathrm{RSC} \\
(\mathrm{Me} / \mathrm{L})\end{array}$ & $\begin{array}{l}\text { PI } \\
(\%)\end{array}$ & $\begin{array}{c}\text { MAR } \\
(\%)\end{array}$ & $\mathrm{KR}$ & \\
\hline Fulpur, M'singh Dist. & 0.41 & 13.4 & - & 0.44 & - & - & - & Shahidullah [26] \\
\hline Pabna district & 0.63 & 28.5 & 4.47 & 3.71 & 73 & 17.54 & 0.22 & Sarkar [16] \\
\hline Satkhira Dist. & 5.66 & 55.91 & 1.18 & - & 80 & 18.29 & 1.59 & Tanvir [83] \\
\hline Comilla District & 2.40 & 44.14 & 0.81 & - & - & 58.97 & 0.74 & Prodip [84] \\
\hline Botiaghata, Khulna Dist & 12.64 & 71.37 & 3.29 & - & - & 54.78 & 6.82 & Didar-Ul [81] \\
\hline Gopalganj Dist. & 10.9 & 61.97 & -0.57 & -1.92 & 67.31 & 57.53 & 2.83 & Atikul [72] \\
\hline Sunamganj District & 15.29 & 38.01 & 0.7 & - & 92.71 & 58.0 & 1.74 & Raihan [28] \\
\hline Joypurhat District & 0.43 & 14.91 & -0.49 & 1.55 & 56.48 & 10.92 & 0.17 & Islam [85] \\
\hline Patuakhali District & 80.73 & 50.56 & -2.83 & -15.0 & 74 & 52.26 & 13.17 & Atikul [72] \\
\hline Brahmanbaria & 0.41 & 21.50 & 1.17 & 0.6 & - & 49.5 & 0.002 & Mahmud [86] \\
\hline Bogra District & 0.23 & 24.42 & - & 2.26 & 89.8 & - & 0.27 & Sammi [87] \\
\hline Trisal, M'singh Dist & 1.94 & 47.80 & 0.75 & - & 79.28 & - & - & Shirazi [10] \\
\hline Khulna District & 9.67 & 62.40 & 29.18 & 29.18 & 87.1 & 25.94 & 2.09 & Sultan [27] \\
\hline Faridpur District & 0.76 & 36.95 & - & -0.62 & - & - & 0.49 & Shaik [88] \\
\hline
\end{tabular}

*According to (chronologically): Ayers and Westcot [33], Eaton [89], Todd [56], Clesceri [90], Doonen [63], Richard [60], Gupta [71], Kelley [64], Raghunath [55], Freeze [91], and Wilcox [74].

The IWQ index is an exclusive index value to assess the suitability of the irrigation water quality in the study area. Table 6 shows that the IWQ values of selected water samples of different regions of Bangladesh and Figure 6 shows three-class values (\%) according to the suitability map obtained from the calculated index values. Using Equations 1 and 2 of Section 3.1, IWQ index was computed for the groundwater samples of 11 selected districts of Bangladesh. When the calculated value ranges from 22 to 37 , the corresponding water exhibits medium suitability for irrigation purposes. The values of over 37 indicated that the groundwater of this region is suitable for irrigation and could be easily used for agriculture purposes. The computed IWQ index values are less than 22 demonstrate the low suitability for irrigation water. The result showed that the groundwater of the coastal belt in Bangladesh is having a high salinity hazard and the IWQ $_{\text {index }}$ values were found to be less than 22. It indicated that the groundwater of the coastal areas was unfit for irrigation uses. The study suggested that groundwater extraction for irrigation purposes of the areas must be considered with caution for sustainable groundwater management. The water quality of the other part of the country is almost safe for agricultural activity.

Table 6. Physico-chemical irrigational groundwater quality of Bangladesh (selected 11 District)

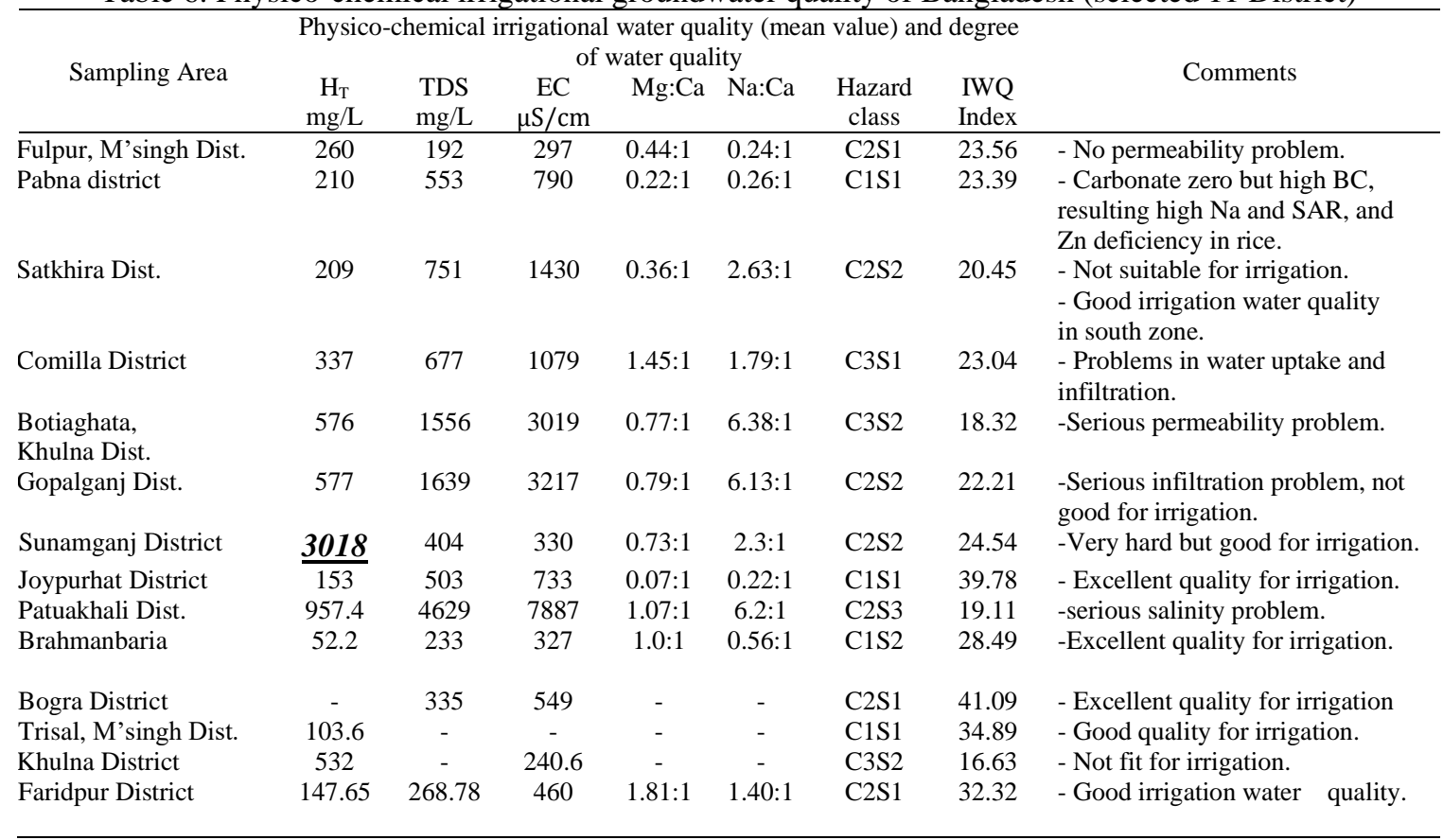



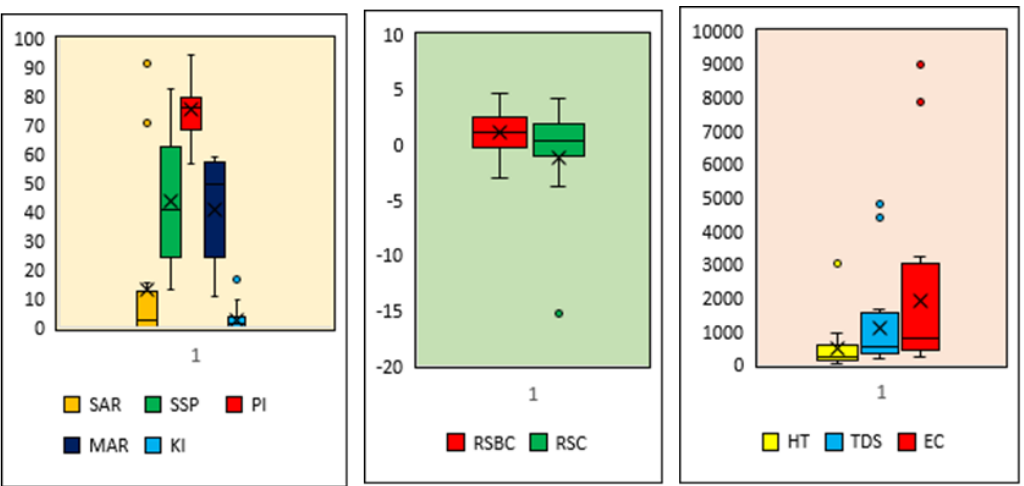

Figure 4. Box plot of irrigation water quality parameters
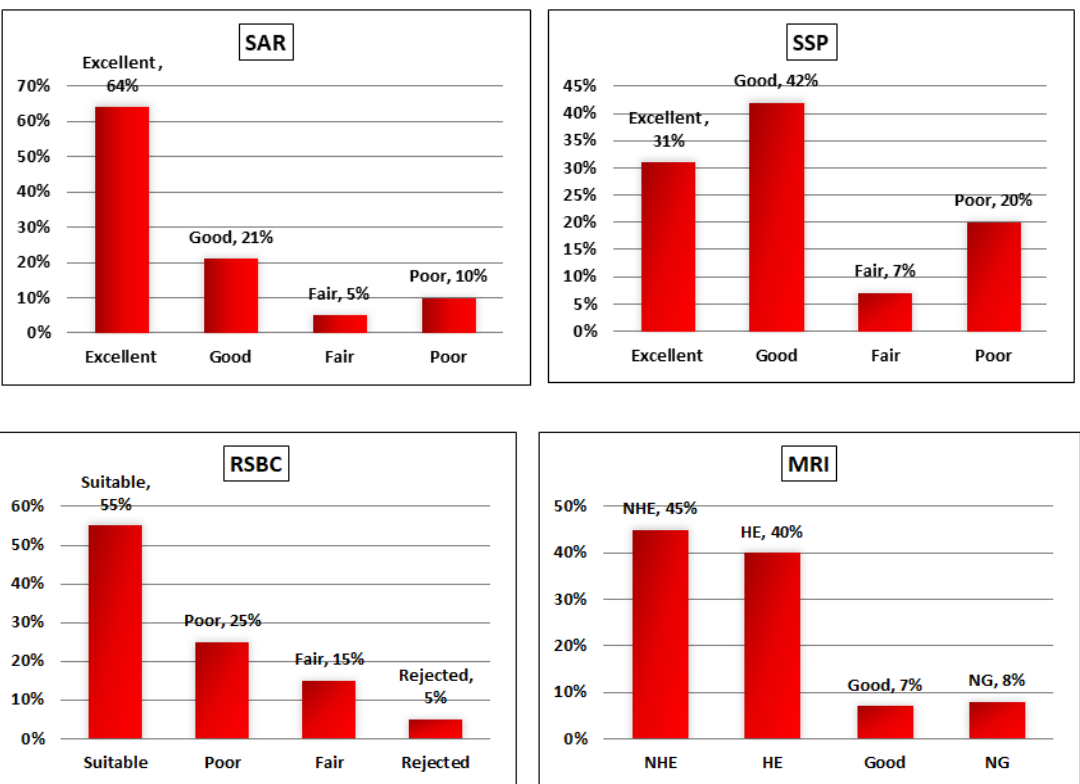

Figure 5. The values of SAR, SSP, RSBC, and MRI in groundwater samples of the various regions of Bangladesh

Table 7. The range of irrigation water quality (IWQ) index

\begin{tabular}{lll}
\hline IWQ $_{\text {index }}$ & Ratting factors & Suitability of water for irrigation \\
\hline$<22$ & 1 & Low \\
$22-37$ & 2 & Medium \\
$>37$ & 3 & High \\
\hline
\end{tabular}

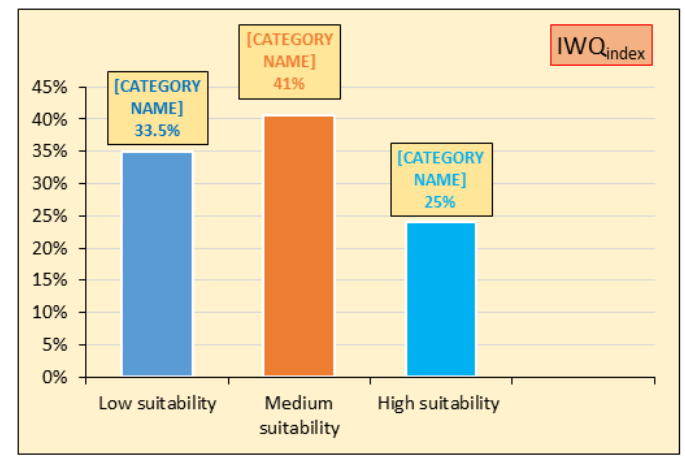

Figure 6. The IWQ index value of the study area's groundwater suitability for irrigation 


\section{CONCLUSION}

To evaluate the irrigation water quality in Bangladesh (BDP), collected secondary data regarding several water quality indices (EC, salinity hazard, hardness, sodium percentage, permeability index, sodium adsorption ratio, magnesium hazard, Kelly's ratio) from the groundwater samples of selected 11 districts. The spatial analysis of the IWQ index illustrates that higher score values for irrigation were observed in the north and north-west side of the country, whereas lower score values show in the southern coastal zones of Bangladesh. According to the score of $\mathrm{IWQ}_{\text {index }}$, it found that $25.5 \%$ of the samples (6 Districts) belong to a high suitability water class, while $41 \%$ and $33.5 \%$ exhibit medium and low suitability classes for irrigation activities in the country. The shallow-deep water of coastal areas (15\% of the country area) holds excess salt and brackish water, for this reason, the water is completely unfit for irrigation. In the present study, EC, TH, TDS, SAR, SSP, MAR, RSBC, and KR values reveal that, except seaside zones, the groundwater samples belong to excellent to good quality types for irrigation uses. The hazard class of southern groundwater samples found C2S2, C3S2, or/and C2S3 categories. The study results showed a consistent index that can be used to regulate the irrigation water quality of any area. These approaches could be used to ensure the quality of groundwater consumption for agricultural purposes. Multiple water indices can be applied to prevent water deterioration, and thus, contribute to the sustainable management and policy adaptation of groundwater resources in Bangladesh.

\section{REFERENCES}

[1] Ahmed K. M, Imam M. B, Akhter S. H, Hasan M. A, Khan A. A, "Sedimentology and mineralogy of arsenic contaminated aquifers in the Bengal Delta of Bangladesh," Groundwater arsenic contamination in the Bengal Delta Plain of Bangladesh, Proceedings of the KTH-Dhaka University Seminar, University of Dhaka, Bangladesh, TRITA-AMI Report 3084,2001, pp. 97-108.

[2] Goodbred S, Kuehl S. A, "The significance of large sediment supply, active tectonism, and eustasy on margin sequence development: Late Quaternary stratigraphy and evolution of the Ganges-Brahmaputra delta," Sedimentary Geology, vol. 133, no. 3-4, pp. 227-248, 2000. [Online] Available: http://doi:10.1016/S0037-0738(00)00041-5.

[3] Reimann C, Filzmoser P, Garrett R, Dutter R, "Statistical data analysis explained: Appliedn Environmental Statistics with R," Wiley, US, 2011.

[4] Khan FH, "Geology of Bangladesh,” Dhaka: The University Press Limited, Bangladesh, 1991.

[5] BBS, "Bangladesh Bauru of Statistics," Annual report, 2019.

[6] UNDP (United Nation Development Programme), "Ground- water Survey: The Hydro-Geological Conditions of Bangladesh," Scientific Research An Academic Publisher, Technical Report, UNDP, New York, 1982, DP/UN/BGD-74-009/1.

[7] D. Kinniburgh, P L. Smedley, "Arsenic contamination of groundwater in Bangladesh Vol 1: Summary," British Geological Survey Report WC/00/19, 2001.

[8] Shamsudduha M, Joseph G, Haque S, S Khan, M. R, Zahid A, Ahmed K. M. U, "Multi-Hazard Groundwater Risks to the Drinking Water Supply in Bangladesh," Exposure and Health Springer, pp. 1-14, 2019.

[9] Asad Sarwar Qureshi, Zia Uddin Ahmed, Timothy J. Krupnik, "Groundwater management in Bangladesh: An analysis of problems and opportunities," Central System Initiative for South Asia - Mechanization and Irrigation, USAID, Research Report No. 2. Dhaka. [Onlone] Available: https://doi.org/10.13140/2.1.2381.9040.

[10] Shirazi S. M, Akib S, Salman F. A, Alengaram U. J, Jamneel M, "Agroecological aspect of groundwater utilization: A case study," Scientific Research and Essay, vol. 5, no. 18, pp. 2786-2795, 2010.

[11] Bangladesh MICS, "Bangladesh Mics 2012-2013 Water quality thematic report," Bangladesh Bureau of Statistics Statistics Division, Ministry of Planning Government of the People's Republic of Bangladesh, UNICEF and BBS, Bangladesh, 2018.

[12] BBS, "Yearbook of Agricultural Statistics of Bangladesh," Bangladesh Bureau of Statistics, p. 332, 21th edition January 1, 2010.

[13] Donald R. Rowe, Isam Mohammed Abdel Magid, "Handbook of Waste Water Reclamation and Reuse," CRC Press, 1995.

[14] Talukder MSU, Shirazi SM, Niazuddin M, and Ghosh AK, "Groundwater quality and its impact on soil and crop, Bangladesh,” Journal Agricultural Science, vol. 26, no. 3, pp. 153-160, 1999.

[15] Abdulrasoul M. Al-Omran, A. R. Al-Harbi, Mahmoud A. Wahb-Allah, Mahmoud Nadeem, Ali Al-Eter, "Impact of irrigation water quality, irrigation systems, irrigation rates and soil amendments on tomato production in sandy calcareous soil," Turkish Journal Agricultural, vol. 34, pp. 59-73, 2010.

[16] Sarkar A. A, Hassan A. A, "Water quality assessment of a groundwater basin in Bangladesh for irrigation use," Pakistan Journal of Biological Sciences, vol. 9, pp. 1677-1684, 2006.

[17] Bauder T. A, Waskom R. M, Sutherland P. L, Davis J. G, "Irrigation Water Quality Criteria," Colorado State University extension, Fact Sheet No. 0.506, 2011.

[18] Foster S, Shah T, "Groundwater resources and irrigated agriculture making a beneficial relation more sustainable," Global Water Partnership Perspectives Paper (Stockholm), 2012.

[19] Bhuiyan M. A. H, Ganyaglo S, Suzuki S, "Reconnaissance on the suitability of the available water resources for irrigation in Thakurgaon District of northwestern Bangladesh," Applied Water Science, vol. 5, no. 3, pp. 229-239, 2014. [Online] Available: http:// doi.org/10.1007/s13201-014-0184-8. 
[20] Dey N, Saha R, Parvez M, Bala S, Islam AKM, Paul J, Hossain M, "Sustainability of Groundwater Use for Irrigation of Dry-Season Crops in Northwest Bangladesh," Groundwater for Sustainable Development, vol. 4, pp. 66-67, 2017. [Online] Available: http://doi:10.1016/j.gsd.2017.02.001.

[21] Capar G, Dilcan C. C, Aksit C, Arslan S, Celik M, Kodal S, "Evaluation of irrigation water quality in Gölbaş1 District," Tarim Bilimleri Dergisi-Journal Agricultural Science, vol. 22, pp. 408-421, 2016.

[22] Mridha M. A. K, Rashid M. H, Talukder K. H, "Quality of groundwater for irrigation in Natore district Bangladesh,” Journal Agricultural Research, vol. 21, pp. 15-30, 1996.

[23] Towfiqul Islam A. R. M, Shen S, Bodrud-Doza M, Safiur Rahman M, "Assessing irrigation water quality in Faridpur district of Bangladesh using several indices and statistical approaches," Arabian Journal of Geosciences, vol. 10, no. 9, pp. 1-25, 2017. [Online] Available: http://doi:10.1007/s12517-017-3199-2.

[24] Quddus K. G, Zaman M. W, "Irrigation water quality in some selected villages of Meherpur in Bangladesh," Journal Agricultural Science, vol. 23, no. 1, pp. 51-57, 1996.

[25] Talukder MSU, Shirazi SM, Paul UK, "Suitability of groundwater for irrigation at Karimganj Upazila Kishoreganj," Progress Agricultural, vol. 9, no. 1-2, pp. 107-112, 1998.

[26] Shahidullah S. M, Hakim M. A, Alam M. S, Shamsuddoha A. T. M, “Assessment of Groundwater Quality in a Selected Area of Bangladesh," Pakistan Journal of Biological Science, vol. 3, no. 2, pp. 246-249, 2000.

[27] MT Sultan, SM Billah, "Irrigation water quality of surface and ground water used for Boro rice cultivation in Khulna district in Bangladesh," Bangladesh Journal of Scientific and Industrial Research, vol. 54, no. 3, pp. 263274, 2019. [Online] Available: http://doi:10.3329/bjsir.v54i3.42679.

[28] Raihan F, Alam J. B, “Assessment of groundwater quality in Sunamganj of Bangladesh,” Iranian Journal of Environmental Health Science \& Engineering, vol. 5, pp. 155-166. 2008.

[29] Islam M. S, Z. K. M. Shamsad, "Assessment of irrigation water quality of Bogra district in Bangladesh," Bangladesh Journal of Agricultural Research, vol. 34, no. 4, pp. 597-608, 2009.

[30] Mirza A. T. M. Tanvir Rahman, Syed Hafizur Rahman, Ratan Kumar Majumder, "Groundwater quality of irrigation of deep aquifer in southwestern zone of Bangladesh," Songklanakarin Journal of Science and Technology, vol. 34, no. 3, pp. 345-352, 2012.

[31] M. F. Serder, M. S. Islam, M. R. Hasan, M. S. Yeasmin, M. G. Mostafa, "Assessment of coastal surface water quality for irrigation purpose," Water Practice \& Technology, vol. 15, no. 4, pp. 960-972, 2020.

[32] Horton R. K, “An index number system for rating water quality," Journal of Water Pollution Control Federation, vol. 37, no. 3, pp. 300-306, 1965.

[33] Ayers R. S, Westcot D. W, "Water quality for agriculture," Food and Agriculture Organization (FAO) of the United Nations, Rome, Italy, 1985, pp. 1-117.

[34] Zaman M, Shahid S, Heng L, "Irrigation Water Quality. Guideline for Salinity Assessment, Mitigation and Adaptation Using Nuclear and Related Techniques,” Springer Nature, pp. 113-132. 2018.

[35] Hussain H. M, Joshi H, Singhal D. C, Kumar S, Rao M. S, "Development of an index of aquifer water quality within GIS environment," Iranian Journal of Earth Sciences, vol. 4, no. 1, pp. 44-50, 2012.

[36] Bozdag A, "Combining AHP with GIS for assessment of irrigation water quality in Cumra irrigation district (Konya), Central Anatolia, Turkey,” Environmental Earth Sciences, vol. 73, pp. 8217-8236, 2014.

[37] Sebnem Arslan, "Assessment of groundwater and soil quality for agricultural purposes in Kopruoren Basin, Kutahya, Turkey," Journal of African Earth Sciences, vol. 131, pp. 1-13, 2017.

[38] Celalettin Simsek, Orhan Gunduz, "IWQ Index: A GIS-Integrated Technique to Assess Irrigation Water Quality," Environmental Monitoring and Assessment, vol. 128, pp. 277-300, 2007.

[39] Ashraf S, Afshari H, Ebadi A. G, "Geographical information system techniques for evaluation of groundwater quality," American Journal of Agricultural and Biological Sciences, vol. 6, no. 2, pp. 261-266, 2011.

[40] Romanelli A, Lima M. L, Londono O. M. Q, Mart1'nez D. E, Massone H. E, "A GIS-based assessment of groundwater suitability for irrigation purposes in flat areas of the Wet Pampa Plain, Argentina," Environmental Management, vol. 50, pp. 490-503, 2012.

[41] "Phase I, Groundwater Studies of Arsenic Contamination in Bangladesh," Department of Public Health Engineering, Government of Bangladesh, British Geologic Survey, and Mott MacDonald Ltd, Keyworth UK, 1999. [Online] Available: http://bicn.com/acic/resources/infobank/bgs-mmi/risumm.htm.

[42] Zahid A, "Groundwater management aspects in Bangladesh," Technical Report, Center for Water and Environment, Bangladesh Water Development Board, 2015.

[43] Aggarwal P. K, Froehlich K, Basu, A. R, Poreda R. J, Kulkarni K. M, Tarafdar S. A, Ali Mohamed, Ahmed Nasir, Hussain Alamgir, Rahman Mizanur, Ahmed Syed Reazuddin, “A report on Isotope Hydrology of Groundwater in Bangladesh: Implications for Characterization and Mitigation of Arsenic in Groundwater," International Atomic Energy Agency, Department of Technical Co-operation, Vienna Austria, 2000.

[44] Zahid A, Hassan, M Q, Nahar M. N. K, "Assessment of hydraulic connectivity of the multi-layered aquifers," The Dhaka University Journal of Earth and Environmental Sciences, vol. 1, no. 1, pp. 13-17, 2010.

[45] Mojid M. A, Parvez M. F, Mainuddin M, Hodgson G, "Water Table Trend-A Sustainability Status of Groundwater Development in North-West Bangladesh," Water, vol. 11, pp. 1-15, 2019. [Online] Available: https://doi.org/10.3390/w11061182.

[46] MPO, "The Groundwater Resource and its Availability for Development," Master Plane Organization, Technical Report No. 5, Ministry of Irrigation, Water Development and Flood Control, Dhaka, 1987.

[47] Alsubal S, Sapari N. B, Harahap I. S. H, "Numerical simulation of groundwater rising due to rainfall at far field in triggering landslide," International Journal of Advanced and Applied Sciences, vol. 5, no. 10, pp. 76-86, 2018. 
[48] Hoque M. A, Hoque M. M, Ahmed K. M, "Declining groundwater level and aquifer dewatering in Dhaka metropolitan area, Bangladesh: causes and quantification," Hydrogeol Journal, vol. 15, pp. 1523-1534, 2007.

[49] Department of Public Health Engineering, "Final report on development of deep aquifer database and preliminary deep aquifer map (First Phase)," Local Government Division, Ministry of LGRD and Co-operatives, Government of the People's Republic of Bangladesh, 2006.

[50] Davies J, Exley C, "Short Term BGS Pilot Project to Assess the Hydrochemical Character of the Main Aquifer Units of Central and North-eastern Bangladesh and Possible Toxicity of Groundwater to Fish and Humans," Final report, 1992.

[51] Hoque M, Hasan M. K, Ravenscroft P, "Investigation of groundwater salinity and gas problems in southeast Bangladesh, Groundwater resources and development in Bangladesh," Bangladesh Centre for Advanced Studies (BCAS), University Press Ltd, Dhaka, 2003.

[52] Mostafa M. G, Helal Uddin, S. M, Haque A. B. M. "Assessment of Hydro-geochemistry and Groundwater Quality of Rajshahi City in Bangladesh," Applied Water Science, Sprringer Link, vol. 7, pp. 4663-4671, 2017.

[53] Burgess T. M, Webster R, "Optimal interpolation and isarithmic mapping of soil properties. I: the semi variogram and punctual kriging," Journal of Soil Science, vol. 31, no. 2, pp. 315-331, 1980.

[54] Michael A. M, "Irrigation Theory and Practices," New Delhi: Vikash Publishing House Pvt. Ltd. India, pp. 686740, 2009.

[55] Raghunath H. M, “Ground water,” New Age International Publisher; 3rd. Ed. Edition, January 1, 2007.

[56] Todd D. K, Larry W. Mays, "Groundwater hydrology," New York: John Wiley and Sons Inc., U.S.A. pp. 10-138, 2004.

[57] Hem J. D, "Study and Interpretation of the Chemical Characteristics of Natural Water," 2nd ed., U.S. Geo. Survey. Water Supply, 1970.

[58] Islam Kamrul, Rahman M. Saidur, Ali M. Hazrat, Hossain A. F. M. Afzal, Alam M. Jahangir, Zahid Anwar, "Evolution of the Aquifers System and Groundwater Quality of the North-west District of Bangladesh for Development Potential," BRAG University Journal. vol. 11, no. 2, pp. 85-100, 2016.

[59] Alrajhi A, Beecham S, Bolan N. S, Hassanli A, "Evaluation of soil chemical properties irrigated with recycled wastewater under partial root-zone drying irrigation for sustainable tomato production," Agricultural Water Management, vol. 161, pp. 127-135, 2015.

[60] Richards L. A, "Diagnosis and Improvement of Saline and Alkali Soils," USDA and IBH Publishing Co. Ltd, New Delhi, India, 1968, pp. 98-99.

[61] N. Subba Rao, A. Subrahmanyam, S. Ravi Kumar, N. Srinivasulu, G. Babu Rao, P. Surya Rao, G. Venkatram Reddy, "Geochemistry and quality of groundwater of Gummanampadu sub-basin, Guntur District, Andhra Pradesh, India," Environmental Earth Sciences, vol. 67, no. 5, pp. 1451-1471, 2012.

[62] Gupta U. C, Gupta S. C, "Trace element toxicity relationships to crop production and livestock and human health: implications for management," Communications in Soil Science and Plant Analysis, vol. 29, no. 11-14, pp. 1491$1522,1998$.

[63] Doneen L. D, "Notes on Water Quality in Agriculture," Published as a Water Science and Engineering, Paper 4001, Department of Water Sciences and Engineering, University of California, Davis, 1964.

[64] Kelley W. P, "Use of saline irrigation water.” Soil Science, vol. 95, no. 6, pp. 385-391, 1963.

[65] Huq S. M. I, Naidu R, "Arsenic in groundwater of Bangladesh: Contamination in the food chain. Arsenic Contamination in Bangladesh,” ITN Bangladesh, Dhaka, 2005, pp. 69-72.

[66] BADC, "Survey report on irrigation equipment and irrigated area in Boro/2001 season," Bangladesh Agricultural Development Corporation BADC, Dhaka. 2002.

[67] M. Ashraf Ali, A. B. M. Badruzzaman, M. A. Jalil, M. Delwar Hossain, M. Feroze Ahmed, Abdullah Al Masud, Md. Kamruzzaman, M. Azizur Rahman, "Fate of arsenic extracted with groundwater," 2003. [Online] Available: https://bvs.per.paho.org/bvsacd/arsenico/arsenic/Ali.pdf.

[68] M. Aziz Hasan, K. Matin Ahmed, Ondra Sracek, Prosun Bhattacharya, Mattias von Brömssen, Sandra Broms, Johan Fogelström, M. Lutful Mazumder, Gunnar Jacks, "Arsenic in shallow groundwater of Bangladesh: investigations from three different physiographic settings," Hydrological Journal, vol. 15, pp. 1507-1522, 2007.

[69] Wallace J. S, Batchelor C. H, "Managing water resources for crop production," Philosophical Transactions of the Royal Society B: Biological Sciences, vol. 352, no. 1356, pp. 937-947, 1997.

[70] Matthess G, “The Properties of Ground Water,” New York: John Wiley and Sons, USA, pp. 397, 1982.

[71] Guy F, "Irrigation Water Quality Standards and Salinity Management Strategies," Texas A\&M University, Texas AgriLife Extension Service: College Station, Texas. Publication B-1667, 2003.

[72] M. Atikul Islam, Md. Mostafizur Rahman, Md. Bodrud-Doza, Md. Iftakharul Muhib, Mashura Shammi, Anwar Zahid, Yeasmin Akter, Masaaki Kurasaki, "A study of groundwater irrigation water quality in south-central Bangladesh: a geo-statistical model approach using GIS and multivariate statistics," Acta Geochimica, Springer. Vol. 37, pp. 193-214, 2018.

[73] UCCC, "Guidelines for interpretations of water quality for irrigation," University of California Committee of Consultants UCCC, U.S.A. National field manual, US - Geological Survey. 1974.

[74] Wilcox L.V, "lassification and use of irrigation water. U.S. Department of Agriculture," Circular No. 969, Washington D.C. USA, 1955.

[75] Rahman M. S, Saha N, Islam A. R. M. T, Shen S, Bodrud-Doza M, "Evaluation of Water Quality for Sustainable Agriculture in Bangladesh," Water Air Soil Pollut, vol. 228, no. 10, pp. 1-16, 2017.

[76] Brammer H, "Bangladesh's dynamic coastal regions and sea-level rise," Climate Risk Management, Elsevier, vol. 1, pp. 51-62, 2014. 
[77] Islam Md, S. M. M. Majumder, "Alkalinity and Hardness of Natural Waters in Chittagong City of Bangladesh," International Journal of Science and Business, vol. 4, no. 1, pp. 137-150, 2020.

[78] Dipankar Chakraborti, Mohammad Mahmudu rRahmana, Bhaskar Das, Matthew Murrill, Sankar Dey, Subhas Chandra Mukherjee, Ratan Kumar Dhar, Bhajan Kumar Biswas, Uttam Kumar Chowdhury, Shibtosh Roy, Shahariar Sorif, Mohammad Selim, Mahmuder Rahman, Quazi Quamruzzaman, "Status of groundwater arsenic contamination in Bangladesh: a 14-year study report," Water Research, vol. 44, no. 19, pp. 5789-5802, 2010.

[79] Dittmar J, Voegelin A, Maurer F, Roberts L. C, Hug S. J, Saha G. C, "Arsenic accumulation in a paddy field in Bangladesh: seasonal dynamics and trends over a three-year monitoring period," Environmental Science Technology, vol. 44, no. 8, pp. 2925-2931, 2010.

[80] Meharg A. A, Rahman M. M, Arsenic contamination of Bangladesh paddy field soils: implications for rice contribution to arsenic consumption," Environmental Science Technology, vol. 37, no. 2, pp. 229-234, 2002.

[81] S. M. Didar-Ul Islam, Mohammad Amir Hossain Bhuiyan, Tanjena Rume, Gausul Azam, "Hydrogeochemical investigation of groundwater in shallow coastal aquifer of Khulna District, Bangladesh," Applied Water Science, vol. 7, pp. 4219-4236, 2017.

[82] World Health Organization, "Guidelines for Drinking-Water Quality," Geneva, 1993.

[83] Poonam Tirkey, Tanushree Bhattacharya, Sukalyan Chakraborty, Suman Baraik, "Assessment of groundwater quality and associated health risk: a case study of Ranchi City, Jharkhand, India," Groundwater for Suistainable Development, vol. 5, pp. 85-100, 2017.

[84] Prodip K. Roy, B. Roy, Bikash C. Roy, "Assessment of Groundwater Quality for Drinking and Irrigation Purposes in Comilla District of Bangladesh," International Journal of Scientific and Research Publications, vol. 6, no. 7, pp. $52-56,2016$.

[85] A. R. M. Towfiqul Islam, Shuanghe Shen, Muhammed Atikul Haque, Md. Bodrud-Doza, K. W. Maw, Md. Ahosan Habib, "Assessing groundwater quality and its sustainability in Joypurhat district of Bangladesh using GIS and multivariate statistical approaches," Environment Development and Sustainability, vol. 20, pp. 1935-1959, 2018.

[86] Mahmud R, Inoue N, Sen R, "Assessment of irrigation water quality by using principal component analysis in arsenic affected area of Bangladesh," Journal Soil Nature, vol. 1, no. 2, pp. 08-17, 2007.

[87] Mashura Shammi, Rashadur Rahman, Md. Mostafizur Rahman, Md. Moniruzzaman, Md. Bodrud-Doza, Bikash Karmakar, M. Khabir Uddin, "Assessment of salinity hazard in existing water resources for irrigation and potentiality of conjunction uses: a case report from Gopalganj District, Bangladesh," Sustainable Water Resources Management volume, vol. 2, no. 4, pp. 369-378, 2016.

[88] Shaik MB, Tipu MMH, Raunak, Mokhlesur RM, "Groundwater Quality and Its Suitability Assessment for Irrigation and Drinking in Different Aquifers of Faridpur, Bangladesh," Journal of Water Pollution \& Purification Research, vol. 2, no. 3, pp. 5-14, 2015 .

[89] Eaton F. M, "Significance of carbonate in irrigation water," Soil Science, vol. 69, no. 2, pp. 123-134, 1950.

[90] Andrew D Eaton, Lenore S Clesceri, Arnold E Greenberg, Mary Ann H Franson, "Standard Methods for the Examination of Water and Wastewater," 17th Edn, American Public Health Association, Washington DC, pp: 1175,1998

[91] Freeze R. A, Cherry J. A, “Groundwater,” Prentice Hall Inc, Englewood Cliffs, vol 7632, 1979.

[92] Vandenbohede A, Courtens C, William de Breuck L, "Fresh-salt water distribution in the central Belgian coastal plain: an update," Geologica Belgica, vol. 13, no. 3, pp. 163-172, 1979.

[93] Sawyer G. N, McCarthy D. L, "Chemistry of sanitary engineers," 2nd Edn. McGraw Hill, New York, 1967, pp. 518.

[94] Asaduzzaman M, "Handbook of Groundwater and Wells," 1st Edn, Dhaka: BRAC Prokashana, Bangladesh. pp. 196-207. 1985. 